\title{
A study on the practice of adulteration of Kitul (Caryota urens) sap products in Sri Lanka
}

\author{
M. A. P. K. Seneviratne* and D. M. D. K. S. Dissanayake \\ Department of Export Agriculture, Peradeniya, Sri Lanka.
}

\begin{abstract}
Kitul (Caryota urens) industry is a traditional agro-based cottage industry in Sri Lanka. By seasoning an immature inflorescence and slicing it, sap can be extracted to make a variety of products such as treacle, jaggery, toddy and vinegar. Genuine Kitul products are used in indigenous medical treatments and also exhibit anti-diabetic properties. It was observed that the quality of sap products was deteriorated by adding cane sugar, hence beneficial effects could not be obtained. The objective of the study was to identify the reasons for sugar adulteration and recommend measures to minimise this malpractice.
\end{abstract}

A questionnaire survey was conducted covering all the 12 Kitul growing districts in Sri Lanka. A two-stage stratified sampling technique was adopted for data collection. A total of 304 tappers from 101 villages were included in the sample. Data were analysed by fitting linear logistic models using SAS statistical package.

The main reason for adulteration of Kitul produce with sugar was low quality sap with high water content. Those tappers who would season flowers and obtain sap during rainy weather had adulterated their Kitul products with sugar $(\mathrm{p}=0.02)$. Similarly, when the success of seasoning a flower was less than $69 \%$, the producers tended to add sugar to their Kitul products $(\mathrm{p}<0.01)$. Furthermore, those tappers who practiced Kitul tapping as the main income source and who obtained sap continuously for more than six months had added sugar to treacle and jaggery products $(\mathrm{p}=0.08)$.

Prevention of rain water being mixed with sap during sap collection is one way of avoiding watery sap. Adoptation of seasoning methods which utilise natural herbal substances is a solution for low success of seasoning of inflorescences. Since low quality sap is secreted during the last phase, when collecting sap for an extended period like six months, the tappers have to be discouraged from tapping the same inflorescence and must be encouraged to find new inflorescences to start tapping.

Keywords: Kitul, sap, sugar-adulteration, qualitydeterioration, success- of-seasoning

\section{INTRODUCTION}

Kitul is a tree belonging to the family Palmae. The sap extracted from its inflorescence is used for making a variety of products such as treacle, jaggery, toddy and vinegar. The treacle and jaggery are sweet products made by concentrating Kitul sap. An immature inflorescence has to be seasoned for easy slicing and extracting of sap by delaying its maturity.

Kitul industry is important for a fraction of the society, in relation to social and economic aspects of the people, who are engaged in the industry. The tapping of Kitul inflorescences is an ancestral practice. The main livelihood of 7\% of Kitul tappers in Sri Lanka is tapping inflorescences and making treacle and jaggery out of the sap collected (Seneviratne, 2009). Treacle and jaggery products are substitutes for cane sugar in these families. The crystallised sugar called weli-hakuru is also a sugar substitute and is sold in village markets as weli-hakuru patta (a pack of stuff). Kitul jaggery of elephant and peacock shapes had been used as gift items, when paid a courtesy visit to influential persons in villages (Kehelpannala, 1898). Villagers who process Kitul sap receive a substantial income from the sale of these products, thus saving a portion of their otherwise meager income (Ratnayake et al., 1990).

Currently, a bottle of Kitul is sold in the range of Rs. 400-600, whereas a kilo of jaggery is sold in the range of Rs. 650-800. On an average, one inflorescence gives an income of Rs. 21,000 during a tapping season and by tapping single inflorescence, $400-600 \mathrm{~kg}$ of jaggery can be made (Ratnayake et al., 1990).

The total Kitul tree population in the country is nearly 30 million, of which 89,855 (16\% of tappable trees) are tapped (Department of Census and Statistics, 2009). 
This shows that an enormous potential exists for the expansion of this industry. Another strength associated with Kitul industry is that there are 29,607 Kitul tappers in the country and their contribution can be obtained to further expansion of the industry (Department of Census and Statistics, 2009).

Genuine Kitul sweets exhibit several healthy effects. These products show anti-diabetic properties (Ranasinghe et al., 2007); hence diabetic patients can consume them without adverse effects. In indigenous medicine, genuine sap products are used for making concoctions (Jayaweera, 1982). The unadulterated Kitul jaggery is called beheth hakuru, which is used in the indigenous medicine.

It is hard to find genuine Kitul products in the open market. The usual practice is to directly approach treacle and jaggery producers to obtain genuine products whenever needed; especially for medicinal purposes.

The processors' failure to realise the value of genuine Kitul products has led to adulterating them, mainly using cane sugar, expecting financial gains. The adulteration of Kitul products with sugar results in a number of consequences. Addition of excessive quantity of sugar adversely affects health and intended health benefits cannot be obtained. The flavor and real taste of Kitul products are masked by the added sugar. High sugar content in treacle results in the formation of crystals, thus lowering consumer preference. Though the desired texture of jaggery is soft, with the addition of sugar it becomes hard and as a result consumer preference lowers. Maximum potential income can not be received since a difference of prices exists between authentic and adulterated Kitul products. As a result, the credibility among consumers gets diminished. Therefore, the value is affected by decreasing consumer acceptance.

Authentic Kitul products have a high demand in international market as well; hence a potential avenue to popularise them. Adulteration with sugar tarnishes the reputation gained so far for authentic Sri Lankan Kitul products. The damage done to Kitul exports is significant since potential foreign exchange earnings cannot be obtained.

This study is important as it will surface reasons for adulteration of Kitul products with cane sugar. Once the reasons are identified, remedial measures could be proposed to minimise this malpractice to a certain extent. Subsequently, credibility lost among consumers could be reestablished. Besides, capturing of foreign market for Kitul products will become easy.
The objective of the study was to identify the factors associated with adulteration of Kitul sap products with cane sugar and recommend measures to minimise the adulteration of Kitul treacle and jaggery with sugar.

\section{MATERIALS AND METHODS}

Kitul industry is practiced in 12 Districts of Sri Lanka (Table 1). In each District there are villages where treacle and jaggery are produced and sold for livelihood of tappers and their families. In this study Kitul growing villages have been defined as villages where either treacle or jaggery or both are produced for marketing purposes, in addition to their own consumption.

It has been observed that practices related to obtaining sap, such as tapping methods, vary from District to District. In addition, the number of Kitul growing villages also varies from region to region (Gunaratne et al., 1996; Seneviratne et al., 2005). Kandy District has the highest number (106), whereas Kalutara has the lowest number of Kitul villages (16). This variability was considered in sampling by application of two-stage stratified random sampling, with Districts as the first stage and villages within Districts as the second stage. Since the number of tappers per village is more or less same in each district and the number of villages being varied from District to District, it was accounted for, by selecting number of villages in proportion to the number of tappers in the district (Seneviratne et al., 2005).

However, the number of tappers in each village was more or less the same and thus, three tappers were selected from each of the selected village. A list of tappers in each District has been compiled by Seneviratne et al. (2005) and this list was used as the sampling frame. According to the sampling scheme, altogether 304 tappers were included in the sample.

An open-ended questionnaire was administered for data collection. In addition to questionnaire survey, indepth discussions with tappers were also performed during visits.

According to the objectives, the dependent variable considered was adulteration of sap products with sugar. Data were analysed by fitting linear logistic model (McCullagh and Nelder, 1989) to examine possible effects of adulteration of sap products. The collected data were coded and the distributions and relationship were analysed by using the SAS statistical package. 
Table 1: Distribution of Kitul growing villages and selected respondents in different districts

\begin{tabular}{lrrr}
\hline District & $\begin{array}{r}\text { Number of Kitul } \\
\text { growing villages }\end{array}$ & $\begin{array}{r}\text { Number of villages } \\
\text { selected }\end{array}$ & $\begin{array}{r}\text { Number of tappers } \\
\text { selected }\end{array}$ \\
\hline Kandy & 106 & 15 & 45 \\
Matale & 101 & 14 & 42 \\
Badulla & 98 & 14 & 42 \\
Matara & 75 & 11 & 33 \\
Nuwara Eliya & 62 & 9 & 27 \\
Kurunegala & 53 & 8 & 24 \\
Ratnapura & 49 & 7 & 21 \\
Galle & 40 & 6 & 18 \\
Kegalle & 38 & 5 & 15 \\
Moneragala & 37 & 5 & 15 \\
Hambantota & 24 & 4 & 12 \\
Kalutara & 16 & 3 & 10 \\
\hline Total & 699 & 101 & 304 \\
\hline Source: Sen
\end{tabular}

Source: Seneviratne et al. (2005)

\section{RESULTS AND DISCUSSION}

When the Kitul tappers were asked whether sugar was added to their Kitul produce as a habit, $11.5 \%$ replied yes, while $88.5 \%$ replied no. However, all the tappers agreed that they had added sugar at least once to collected sap when they detected fermentation has initiated. The reasons given by the respondents for adulteration are shown in Table 2.

Table 2: Reasons for adulteration of Kitul produce with sugar

\begin{tabular}{lrr}
\hline Reason & $\begin{array}{r}\text { Number of } \\
\text { Respondents }\end{array}$ & Percentage \\
\hline Sap contains more water & 19 & 6.3 \\
Initiation of fermentation in the sap & 11 & 3.6 \\
$\begin{array}{l}\text { No price difference between genuine } \\
\text { products and sugar-added products }\end{array}$ & 4 & 1.3 \\
$\begin{array}{l}\text { Failure to collect sap before it is } \\
\text { fermented }\end{array}$ & 1 & 0.3 \\
\hline
\end{tabular}

Watery sap can be a result of rain water being mixed with sap during rainy weather; draining watery sap at initial stage of tapping and the latter stage of tapping; and tree characteristics.

Initiation of fermentation can be linked to failure of collection of sap on time and delay in boiling of the collected sap. Evening collection of sap tends to ferment faster in comparison to morning collection due to the effect of hot sun. Therefore, tappers used to add some sugar to the evening collection of sap.

Reasons associated with adulterating Kitul products with sugar were examined by fitting linear logistic model and results are given in Table 3. The variables used in the model are depicted in Table 4.
Table 3: Maximum likelihood analysis of variance for adulteration of Kitul products with sugar

\begin{tabular}{lcrr}
\hline Source & DF & Chi-Square & Probability \\
\hline Intercept & 1 & 58.62 & $<0.01$ \\
Source of income & 1 & 0.96 & 0.33 \\
Seasoning of flowers during & 1 & 5.33 & 0.02 \\
rainy weather & 1 & 8.99 & $<0.01$ \\
Success of seasoning flowers & 1 & 0.11 & 0.74 \\
$\begin{array}{l}\text { Duration of tapping } \\
\text { Source of income }{ }^{*} \text { Duration } \\
\text { of tapping }\end{array}$ & 1 & 3.03 & 0.08 \\
\hline Likelihood ratio & 9 & & \\
\hline
\end{tabular}

The natural seasoning mixtures contain substances of plant origin; such as spice-based mixture (having spices like pepper, chilies, ginger, cardamom and garlic etc.) and citrus mixture (comprised of leaves, barks and juice of five varieties of citrus) (Seneviratne et al., 2005). These were traditionally accepted fit for consumption and categorised as natural mixtures. Artificial seasoning mixtures include ingredients like ash and slaked lime, which are not considered fit for human consumption (Seneviratne et al., 2005).

In this study, the success rate has been defined as the number of cases that becomes successful if 100 inflorescences are seasoned (Seneviratne et al., 2013). Once an inflorescence is properly seasoned, the duration of sap collecting exceeds a month.

The results reveal that those tappers who could make flowers and obtain sap during rainy weather have adulterated their Kitul products with sugar $(\mathrm{p}=0.02)$. 
Table 4: Variables used in the linear logistic model

\begin{tabular}{ll}
\hline Variable & Measurement scale \\
\hline Adulteration of Kitul sap with sugar & Age of tapper (more than 45 yrs or less) \\
& Nature of tapping profession (traditional or not) \\
& Source of income (income derived from Kitul tapping or combining with other \\
& income source) \\
& Tapping experience (more than 15yrs or less) \\
& Number of blocks being tapped at a time (more than four or less) \\
& Type of seasoning mixture used for seasoning inflorescences (natural or artificial) \\
& Ability to season flowers during rainy weather (can or cannot) \\
& Mean daily yield (more than 16 bottles or less) \\
& Duration of tapping (more than six months or less) \\
& Success rate (more than 70\% or less) \\
& Kitul growing region (mid-country of southern region) \\
\hline
\end{tabular}

Note that variable adulteration of Kitul sap with sugar was the dependent variable and the others were explanatory variables

Similarly when the success of seasoning flowers is less than $69 \%$, the producers tend to add sugar to their produce ( $\mathrm{p}<0.01$ ) (Table 6). Low success would lead to low production of sap and hence, low income. In order to offset their low income, sugar is added to the produce.

The parameter estimates in relation to Table 3 are given in Table 5. The parameter estimates reveal that odds of ability to season flowers during rainy weather is $\exp [(2)(0.51)]=2.77$ times greater than that of failure to season flowers during rains. This indicates that those who can season flowers during rainy seasons rely significantly on sugar to make their products. This may be due to low concentration of sugar and more water in the sap during rains. The odds of success of seasoning $(>70 \%)$ is $\exp [(2)(0.66)]=3.8$ times greater than that of low success $(<69 \%)$ indicating those who fail to season flowers depend on sugar hoping to increase their income to offset the low level of production and low income.

There is an interaction between income source and duration of tapping. Those tappers who practice Kitul tapping as the main income source and who obtain sap for more than six months continuously have added sugar

Table 5: Analysis of maximum likelihood estimates for adulteration of Kitul products with sugar

\begin{tabular}{lrr}
\hline Effect & Estimate & Standard Error \\
\hline Intercept & -1.80 & 0.236 \\
Income source & -0.19 & 0.198 \\
Seasoning of flowers during & 0.51 & 0.200 \\
rainy weather & & \\
Success of seasoning flowers & 0.66 & 0.221 \\
Duration of tapping & 0.07 & 0.199 \\
Income source ${ }^{*}$ Duration & 0.34 & 0.197 \\
of tapping & & \\
\hline
\end{tabular}

December 2016

to make treacle and jaggery products $(\mathrm{p}=0.07)$. These tappers seem to practice Kitul tapping on a commercial basis. In order to sustain their income, addition of sugar to products can be expected.

A significant association was not observed between adulterating Kitul products with sugar and age of tapper, nature of tapping profession, tapping experience, number of blocks being tapped at a time, type of seasoning mixture used for seasoning inflorescences, mean daily yield, duration of tapping and Kitul growing District (Table 6).

When the respondents were inquired about the health effects of genuine sap products, $80 \%$ of them failed to explain them. This indicates their ignorance on this important aspect. Therefore, it is required to educate them on these aspects. Low quality sap is the main reason for sugar addition to sap produce. Though it is impossible to manipulate secretion of watery sap during rains, it is

Table 6: Level of significance from fitting the model for studied variables

\begin{tabular}{lr}
\hline Variable & P value \\
\hline Ability to season flowers during rainy weather & 0.02 \\
Success of seasoning flowers is less than 69\% & $<0.01$ \\
Age of tappers & 0.28 \\
Nature of tapping profession & 0.98 \\
Tapping experience & 0.55 \\
Number of blocks being tapped at a time & 0.76 \\
Type of seasoning mixture used for seasoning & 0.33 \\
inflorescences & \\
Mean daily yield & 0.80 \\
Duration of tapping & 0.74 \\
Kitul growing District & 0.10 \\
\hline
\end{tabular}

Sri Lanka Journal of Social Sciences 39 (2) 
possible to prevent collection of rain water in the pots by completely covering them. Low success of seasoning is associated with inappropriate seasoning methods (Seneviratne et al., 2012). A number of seasoning methods using natural herbal mixtures, which give high success rates, have been identified (Seneviratne et al., 2005). During rains it was suggested to increase success of seasoning by inclusion of ingredients like bark of papaw roots, drumstick roots and wild chilie species etc. Burning of the base of inflorescence has been found as a successful method of seasoning, especially during rains (Seneviratne et al., 2005). These effective methods have to be introduced to Kitul tappers. Professional tappers who depend on the collection of sap from one tree for an extended period tend to adulterate their sap produce with sugar. Secretion of low quality sap is possible at the last phase (about a month) of sap collection of six month period. They have to be educated on this aspect and discouraged to collect sap at the phase of decreasing sap yield. The option is to motivate them to find new inflorescences in place of old ones when they observe signs of low quality sap of the inflorescence being tapped.

\section{CONCLUSIONS}

In order to maintain sap quality and prevent adulteration of the sap, below measures should be taken at the sap collection level.

Sap colleting pots should be completely covered to prevent rain water accumulation, which results in a watery sap. Effective seasoning mixtures and methods are to be used in increasing the success of seasoning. Collection of sap at the last phase of long duration tapping (more than six months) should be discouraged and new inflorescences must be found for tapping.

\section{REFERENCES}

Department of Census and Statistics. (2009) Statistics on Kithul palms in Sri Lanka. Colombo: National program for Kithul Development, Ministry of Traditional Industries and Small Enterprise Development.

Gunaratne, W. D. L., Premakumara, K. V. S. \& Heenkenda, A. P. (1996) Kitul (Caryota urens L.): A popular multipurpose plant among the rural community. Proceedings of the Seventh Multipurpose Tree Species Workshop. pp: 226-233.

Jayaweera, D. M. A. (1982) Medicinal plants used in CeylonPart 4. Colombo: National Science Council of Sri Lanka.

Kehelpannala, T. B. P. (1898) The Kitul and its uses. Colombo: George J.A. Skeen, Government Printer.

McCullagh, P. \& Nelder, J. A. (1989) Generalized Linear Models. 2nd Ed. London: Chapman and Hall. DOI: http://dx.doi.org/10.1007/978-1-4899-3242-6

Ranasinghe, P., Premakumara, G. A. S., Wijayarathna, D. \& Ratnsooriya, W. D. (2007) Anti-diabetic properties of Caryota urens (Kithul palm) sap and treacle. Internationsl Conference on Chemistry- Technology and Innovation for greater safety and Economic growth, Transasia Hotel, Colombo, Chemtech. pp: 46.

Ratnayake, P. D. K. C., Gunatillake, C. V. S. \& Gunatillake, I. A. U. N. (1990) Caryota urens (Palmae): An indigenous multipurpose tree species in the wet lowlands of Sri Lanka. Research on multipurpose tree species in Asia. Proceedings of an international workshop held Nov. 19-23 in Los Banos, Phillipines. pp: 77-88.

Seneviratne, M. A. P. K. (2009) Technology generation \& transfer process in the Kitul industry of Sri Lanka. Proceedings of the National Symposium on Experiences and Challenges in Agricultural Extension: Meeting Farmer Needs. Gannoruwa, Peradeniya: Plant Genetic Resources Center: pp: 434-445.

Seneviratne, M. A. P. K., Wanigasundara, W. A. D. P. \& Wijeratne, M. (2005) Use of seasoning mixtures for enhancing flow of sap of Kitul (Caryota urens L.) in Sri Lanka. Tropical Agricultural Research. 17. pp: 264-270.

Seneviratne, M. A. P. K., Wanigasundara, W. A. D. P. \& Wijeratne, M. (2012) Factors affecting duration of tapping of Kithul (Caryota urens L.) inflorescences. Proceedings of the Symposium on Minor Export Crops (Ed. B. Marambe). 16-17 August. Peradeniya: Plant Genetic Resources Center. pp: 176183.

Seneviratne, M. A. P. K., Wanigasundera, W. A. D. P. \& Wijeratne, M. (2013) Assessment of tapping skills of Kitul (Caryota urens L.) tappers in Sri Lanka. Proceedings of the Symposium on Minor Export Crops (Ed. B. Marambe). 12-13 September. Peradeniya: Plant Genetic Resources Center. pp: 107-113. 